\title{
Lowe's Companies, Inc. And The Home Improvement Industry In 2007
}

Debora J. Gilliard, (Email: gilliard@mscd.edu), Metropolitan State College of Denver

\section{LOWE'S COMPANIES, INC.}

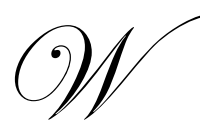

ith the housing boom coming to an end, rising interest rates, and decreasing consumer spending on home improvement products, the home improvement industry is on the brink of change. The industry is seeing increased costs for fuel, raw materials, and lumber in addition to shortages of raw materials. Past years' sales growth rates $(9.3 \%$ in 2005$)$ are expected to slow to $4-5 \%$ as the industry reaches maturity. ${ }^{1}, 2$ Will Lowe's Companies' domestic growth strategy be sufficient in the years to come? Robert Niblock, Lowe's chief executive expressed confidence in the company's ability to maintain its momentum when he stated, "Recent data suggest continued favourable trends in employment levels and income growth which will offset some of the monetary pressures consumers are facing, such as rising fuel prices and interest rates." ${ }^{3}$ He also stated, "As trends in the housing market normalize from the rapid growth experience over the past few years, we believe we have the programs in place to continue to capture share and deliver solid earnings growth."

\section{THE HOME IMPROVEMENT INDUSTRY}

The retail hardware industry has been present for as long as people have owned homes and needed the tools and equipment to maintain, repair, and improve the homes. By the 1970s the industry began to change as hardware stores added lumber products and lumberyards expanded to include hardware products and corporate chains began to emerge. By the 1990s home improvement chains were opening large stores of over 100,000 square feet and expanding from urban population centers into smaller markets. By the end of 2005, the home improvement industry had total sales of $\$ 291.3$ billion $^{5}$ and sales were expected to exceed $\$ 312$ billion in 2006 , reflecting an $8.8 \%$ growth rate. $^{6}$

The National Retail Hardware Association and the Home Center Institute report there are three primary channels of distribution for hardware and home improvement products: hardware stores, home improvement centers, and lumber/building materials outlets. The three types of stores are defined by the products they carry and the customers they sell to. However, all three types of stores sell core products including: hardware, hand and power tools, plumbing/heating products, electrical supplies, paint supplies, home decorating products, and lawn and garden products.

\section{Hardware Stores}

Hardware stores tend to be independent family-owned operations with store sizes of 20,000 to 30,000 square feet and are affiliated with dealer-owned or co-op wholesalers. They serve neighborhood markets and tailor their products and services to the individual markets. They offer personal service and have well-informed salespeople. Their primary customers are homeowners. Widely known hardware stores include True Value, Ace, Do It Best, Trustworthy, Sentry, and PRO.

\section{Home Improvement Centers}

National chains dominate the home improvement center segment of the industry. These stores offer a full range of home repair, maintenance, and improvement products and tend to be very large with many stores over 100,000 square feet. Some chains focus on the do-it-yourself customers while others focus on professional 
customers. Most home improvement centers buy merchandise directly from manufacturers. The largest home improvement center chains are The Home Depot, Lowe's, and Menard's.

\section{Lumber/building Material Outlets}

Although lumber/building material outlets have historically focused on the contractor and builder customers, many are attracting consumers with their 'consumer-oriented' lumberyards. However, 70-80\% of their sales come from lumber and building material sales to traditional contractors, builders, and remodelers. They can be chain stores or independent operations. Well known lumber/building material companies include 84 Lumber, Lanoga, Stock Building Supply, BMC West, Sutherland Lumber, and Foxworth-Galbraith.

Sales and number of outlets for the 3 types of stores for 2005 - 2009 are reported in the Do-It-Yourself Retailing 2005 Annual Report:

\begin{tabular}{|ccc|}
\hline Year & $\begin{array}{c}\text { Sales by Type of Store } \\
\text { In billions Dollars }\end{array}$ & Number of Outlets \\
\hline 2005 & Hardware 32.4 & 20,200 \\
& Home Centers 164.8 & 10,100 \\
& Lumberyards 72.9 & 21,300 \\
\hline 2006 & Hardware 34.1 & 100 \\
& Home Centers 173.1 & 11,000 \\
\hline & Lumberyard 76.6 & 20,100 \\
\hline 2007 & Hardware 35.6 & 10,000 \\
& Home Centers 181.3 & 11,250 \\
\hline 2008 & Lumberyards 80.2 & 20,100 \\
& Hardware 37.3 & 10,000 \\
& Home Centers 189.5 & 11,250 \\
\hline 2009 & Lumberyards 83.8 & 20,000 \\
& Hardware 39.2 & 9,950 \\
\end{tabular}

The home improvement industry is a fragmented industry with over 41,600 store locations. The 25 largest companies have about $51 \%$ of the market share. The three largest home improvement companies -- The Home Depot, Lowe's, and Menard's -- have about $41 \%$ market share. Future sales growth is expected to be between $4 \%$ and 5\% a year. ${ }^{7}$ The National Retail Hardware Association and the Home Center Institute believe independent retailers offer strong competition to larger chains. In annual surveys, they have found that independent retailers show sales floor square footage holding steady, average per store sales rising, and productivity and profitability measurements improving. In addition, the top $25 \%$ of independent retailers report financial performance that is as good, and in some cases better, than corporate chains.

Economic changes are impacting this industry. Changes in bankruptcy laws that went into effect during fall 2005 along with higher interest rates and tightening credit criteria by lenders may keep first-time homebuyers from entering the market. This impacts the growth of home improvement spending - which is typically highest within the first six months after a buyer purchases a home. ${ }^{8}$ Personal income is expected to grow $3.3 \%$ in 2007 compared to a growth rate of $2.6 \%$ in 2006 . Employment growth is strong and low unemployment rates suggest more consumer confidence which has a positive impact on home improvement sales. U.S home ownership is at near record levels which provide a customer base for home maintenance and home repair projects. ${ }^{9}$ Eighty-five percent of the homes in the U.S. were built prior to 1980 and these homes need frequent maintenance and provide a demand for remodeling projects. ${ }^{10}$ Congress passed the Energy Policy Act of 2005 which allows individuals tax credits up to $\$ 500$ when they undertake energy efficient home improvement projects. ${ }^{11}$ 
Demographic trends in the U.S. are reflecting an increasing number of buyers entering the housing market. Generation Xers are buying homes at a younger age than their parents and are interested in personalizing and upgrading the features in their homes. The 72 million Echo Boomers (aka Generation Y) are just beginning to consider home ownership and will begin having an impact on the market in 2007. Continuing immigration also brings many new potential home buyers into the market. ${ }^{12}$ Baby boomers account for more than half of all home improvement expenditures and are expected to increase their spending to remodel and renovate their home once their children move out. It is also expected that the baby boomer generation will increase existing home sales as they either downsize their homes or acquire second vacation/retirement homes. ${ }^{13}$ There is a trend of more women being involved in home improvement projects. About $46 \%$ of the remodeling projects involved women making the final decision compared to $54 \%$ of the men. In addition, single women are purchasing homes at twice the rate of single men. This makes them the fastest growing group of homeowners after married couples. ${ }^{14}$

Internationally the home improvement industry is also experiencing changes. In Europe, Kingfisher plc, which owns the UK chain B\&Q along with the French chain of Castorama, has divested its other businesses in order to focus on its home improvement retail businesses. Because of poor performance in the UK market, Kingfisher is looking abroad for increased growth and profits. ${ }^{15}$ Because Kingfisher has been successful with its 14 B\&Q stores in China, the company plans to open 70 more stores in China within the next 5 years. The German company, Obi, operates 4 stores in China. ${ }^{16}$

Home ownership, which was once forbidden in communist China, is now allowed and this means that there are now millions of potential do-it-yourselfers in the country. Flooring, appliances, and fixtures do not come standard in new home in China, so home owners must purchase and install these items. ${ }^{17}$ At a recent trade show in Hong Kong, it was noted that the fast-growing construction industry in China has stimulated demand for lighting, hardware, and other home improvement products. Hong Kong exported HK\$919 worth of lighting products to mainland China during the first nine months of 2005, which represented an increase of $36 \%$ over the previous period in $2004 .^{18}$

A survey of home builders, which was conducted by Lowe's at the 2006 International Builders' Show, indicates the biggest trend in home building is a focus on energy-efficient materials and products. Windows, insulation, doors, water heaters, and furnaces are the most common upgrades installed by builders to help sell the home or are done at the buyer's request. Smart Home Technology, which includes wiring for such uses as home computers, automated security systems and programmable lighting, has been installed by $57 \%$ of the builders. During 2006, $46 \%$ of builders report they will include home offices in new homes, $41 \%$ will include outdoor living spaces, and $38 \%$ will include elements that allow older home owners to age in place. Home theaters and finished basements are the least likely additions to be installed in new homes during $2006 .{ }^{19}$

Key trends reported at the 2006 Kitchen and Bath Industry Show indicate that comfort is becoming important. Melissa Birdsong, vice president of trend forecasting and design for Lowe's, reports, "A focus on design - from new directions in space planning and functionality to a heightened attention to detail in surface materials and technology - is at the heart of new developments for kitchen and bath. Key style themes included both ends of the spectrum, from very clean, minimal contemporary to fresher interpretations of traditional. Both style expressions used an abundance of natural materials and textures which added a softer, more handcrafted quality." 202006 trends include darker wood tones in kitchen cabinets, new colors in appliances and bath fixtures, and faucets that are in nickel, polished chrome, and bronze. Technology also plays a role in new kitchen and bath products. New ovens now have smart technology that senses the type of food in order to provide optimal cooking performance. Refrigerators with integrated technology provide home owners with food inventories and can create grocery lists which may be sent to cell phones or the local grocery store. Digital one-touch programming offers a spa-like environment in baths, steam showers, or soaking tubs. Toilets can be purchased with heated seats, built-in bidet features, self-cleaning options, and quiet-closing lids. All-in-one washer and dryer units are available and they can offer features such as a steam cycle to reduce wrinkles and humidity sensors that prevent damage to clothes during wash and dry cycles. ${ }^{21}$ 


\section{LOWE'S OPERATIONS ${ }^{22}$}

Lowe's began its life in 1921 when Mr. L.S. Lowe opened the North Wilkesboro Hardware store in North Carolina. By 1945, the store was being run by Mr. Lowe's son, Jim, and his son-in-law, H. Carl Buchan and in 1956 Carl bought the Lowe's share of the company. Carl Buchan kept the Lowe's company name because he liked the slogan "Lowe's Low Prices" and it was consistent with his philosophy of offering low prices to customers. Taking advantage of the post World War II building boom, the company began expanding and by 1960 had 15 stores in 4 states. Although Carl Buchan died in 1960 of a heart attack, the company continued to grow, went public in 1960, began trading on the New York Stock Exchange in 1979, and was eventually renamed Lowe's Companies, Inc. Until 1988, outlets were about 20,000 square feet, but in 1989 when Lowe's was overtaken by Home Depot as the \#1 home retail chain the company began focusing on building larger stores of about 100,000 square feet and phasing out the smaller stores. In 1989 the company entered into a joint venture to sell an exclusive line of Kobalt-brand professional mechanics tools that were produced by Snap-on and the company began allowing contractors to special order items that were not stocked in stores. Lowe's began its expansion into western states in 1999 when it purchased Washington-based Eagle Hardware \& Garden which owned 38 stores. ${ }^{23}$ Today, Lowe's has over 1,385 stores in 49 states and 11 regional distribution centers. Lowe's employs 157,000 full time and 53,000 part time employees. Fiscal Year End 2006 (dated February 2, 2007) sales were \$46.927 billion and FYE 2006 earnings were $\$ 3.105$ billion. The company is ranked \#45 on the 2007 Fortune 500 list, has been named one of Forbe's Best Managed Companies in America, and rated one of the Top 100 Companies Offering Opportunities for Hispanics by Hispanic Magazine. Lowe's Companies serves approximately 13 million customers each week and is committed to offering everyday low prices and a $10 \%$ low price guarantee. ${ }^{24}$

\section{VISION}

Lowe's Companies vision statement is: to be our Customers' first choice for home improvement in each and every market we serve. To earn our Customer's trust and meet their individual needs we will provide valued solutions with the best prices, products and services that make our Customers' lives easier.

Lowe's is taking a number of steps to achieve its vision that include expansion plans and a focus on customer service.

\section{GROWTH}

The company's growth and expansion plan includes 400 new locations that have been approved for 2006 and beyond with 35\% planned for the 25 largest metropolitan markets and 65\% approved for the top 100 markets. At fiscal year end 2006, only $28 \%$ of its stores were in the top 25 national markets and 55\% of the stores were in the top 100 large metro markets. Managers believe that they can expand in the North American market to a total of 2,000 stores. The company opened 155 new stores in 2006 and plans to open 150-160 new stores to open in 2007. In 2007, the company plans to expand into Canada with 6 to 10 stores opening in the Greater Toronto Area and the company has announced it plans to open 3 to 5 stores in Monterrey Mexico by 2009. Lowe's has two prototype floor plans to serve its customers: A 116,000 square foot store for large markets and a 94,000 square for store for smaller markets. Lowe's continues to invest in existing stores by adding new displays, improving signage, adding more products, and repainting buildings.

\section{CUSTOMERS}

As the \#2 ranked company in the home improvement industry, Lowe's focuses on expansion in the domestic market and serving its core customers of contractors, retail do-it-yourself (DYI) customers, and retail do-itfor-me (DIFM) customers. A number of initiatives have been introduced that focus on the vision of being the customers' first choice for home improvement in each and every market Lowe's serves. The most important initiative is the Big 3 sales initiative that involves Installed Sales, Special Order Sales, and sales to the Commercial Business Customer. 
As the market has shifted from do-it-yourself (DYI) to do-it-for-me (DIFM) customers (DIFM account for about $10 \%$ of all home improvement projects ${ }^{25}$ ), Lowe's has responded by offering over 40 categories of installation services. Flooring, millwork, and kitchen cabinets \& countertops generate the most sales and Installed Sales accounted for 6\% of total sales in FY 2006 and grew 9\% during the year.

In order to provide customers an opportunity to purchase unique products, Lowe's has installed a Special Order Sales program. The ordering system provides easy-to-use customer interfaces, integrated design tools, and electronic product catalogs and distribution center locations ensure that special orders will be delivered within 3 business days. Special order kiosks are available in departments throughout the store and may be electronic or literature based. The company has implemented a flexible fulfillment initiative to provide faster and more efficient delivery of special order products to customers by keeping some higher demand products on hand at the distribution centers. The fulfillment option will be refined and enhanced during 2007. The Special Order program grew 25\% in FY 2005 and represented 6\% of sales in FY 2006.

To better serve and build relationships with repairers and remodelers, property management professionals, and professional tradespeople, Lowe's offers convenient one-stop shopping. Contractor packs, which are economical quantities of often used items, are available along with job site delivery seven days a week. Commercial customers can fax or phone in orders that will be ready for pickup the same day. A special website (LowesForPros.com) for commercial customers offers articles, job estimate and business forms, e-newsletters, and other information. Over 25\% of total sales were from Commercial Business Customers in FY 2006.

Today Lowe's customers can more easily shop online at Lowes.com. The website offers customers how-to and buying guides in their search to make good and informed buying decisions on their home improvement projects. Customers can check product availability and make online purchases. Orders can be shipped directly to the customer's location or be picked up at a store. Managers plan to continue to enhance the website by offering more merchandise selection and content to meet customer needs.

Lowe's continues to provide Every Day Low Prices (EDLP) to customers. If customers find a lower price on an identical product at a local competitor, Lowe's will beat the price by $10 \%$. Self-checkouts have been installed in 400 stores with plans to add self-checkouts in 250 stores during 2007. Financing is available to customers through the proprietary credit card, the co-branded Visa credit card, and the Lowe's Project Card which was launched in late 2005. The Project Card provides in-store financing for a major project that a customer engages in with an APR as low as 7.99\%, credit lines up to \$30,000, and repayment terms of 48 to 120 months.

Lowe's is pursing opportunities of expanding its customer base through multicultural marketing designed to target the growing Hispanic and African-American home improvement customer segments. Lowe's has bilingual signage and point-of-purchase materials and offers translation services via telephone. Lowe's management has noted that total home ownership reached 69\% in 2004 and Hispanic home ownership grew three times the average rate.

Lowe's managers believe that customer-oriented initiatives have been successful to date. Comparable store sales increased 6.5\% in 2005 but were flat in 2006, and average ticket for comparable stores increased $6.1 \%$ in 2005 with a small increase in 2006 . The 2006 results were a result of: 1) a mild hurricane season that resulted in lower levels of rebuilding, 2) deflation in lumber and plywood, and 3) a decline in the housing environment.

\section{PRODUCTS}

Lowe's carries over 40,000 items in stores with thousands of additional products available through the Special Order Sales system. A wide selection of name-brand merchandise is available such as Whirlpool, KitchenAid, Samsung, Pella, Werner, Kohler, DeWalt, John Deere, Troy-Bilt, Jenn-Air and many others. Stores also carry many brand names that are exclusive to Lowe's stores in product categories such as paint, lighting, flooring, doors, tools, and windows. These exclusive brands include American Tradition, Mohawk, Premier Living, Kobalt, Portfolio, Harbor Breeze, Perfect Flame, and others. In 2005, Lowe's added John Deere mowers and 
Samsung digital kitchen appliances to its line-up of products. In 2006, the company added high efficiency and innovative laundry products from Whirlpool, Bosch, Electrolux, and Fisher \& Paykel.

Sales by product category for FY 2006 are as follows:

\begin{tabular}{|c|c|c|}
\hline & \$ millions & \% of Total \\
\hline Appliances & 4,193 & 8 \\
\hline Lumber & 3,690 & 7 \\
\hline Millwork & 3,137 & 7 \\
\hline Flooring & 3,214 & 6 \\
\hline Paint & 3,073 & 6 \\
\hline Building materials & 3,002 & 5 \\
\hline Fashion plumbing & 2,893 & 5 \\
\hline Tools & 2,563 & 5 \\
\hline Lighting & 2,573 & 5 \\
\hline Lawn \& Landscape products & 2,356 & 5 \\
\hline Hardware & 2,296 & 4 \\
\hline Seasonal living & 2,154 & 4 \\
\hline Oubinets \& countertops & 1,903 & 4 \\
\hline Rough plumbing & 1,805 & 3 \\
\hline Rough electrical & 1,664 & 3 \\
\hline Nursery & 1,479 & 2 \\
\hline Home environment & 1,454 & 2 \\
\hline Walls/windows & 1,145 & 2 \\
\hline Home organization & 1,101 & 100 \\
\hline TOTAL & 1,001 & \\
\hline
\end{tabular}

Source: Lowe's Companies 2006 Annual Report

Lowe's purchases products from approximately 7,000 vendors worldwide with no single vendor accounting for more than $6 \%$ of total purchases. Item and order information are shared electronically with suppliers. Whenever possible, the Global Sourcing Division buys products directly from foreign manufacturers in order to avoid thirdparty importers and decrease costs.

The company owns 11 Regional Distribution Centers (RDC), 12 flatbed distribution centers and leases 1 flatbed distribution centers and has plans to open two new RDCs in FY 2007 and one in 2008 and plans to open 2 additional flatbed centers in FY 2007. Each RDC services up to 126 stores and efficiently moves products from vendors to stores and maintains in-stock levels. The flatbed distribution centers distribute merchandise that requires special handling due to size or type of packaging and includes such items as lumber, boards, panel products, irrigation pipe, vinyl siding, ladders, and building materials. In order to improve the supply chain infrastructure and ensure that the right products are in the right stores at the right time, Lowe's has implemented its Rapid Response Replenishment (R3) initiative. When the R3 Initiative began in 2004, approximately 50\% of total stock was processed through the distribution network. In FY 2005, approximately 70\% of merchandise was shipped through the distribution network and 30\% was shipped directly to stores from vendors. In FY $200675 \%$ of stock moved through the distribution network.

The company operates 4 facilities to support its import business, special order sales, and internet sales. Two of the facilities are owned and two are leased. The company uses two third-party transload facilities that serve as the receiving point for imported products. The transload facilities sorts and sends products to the RDCs. 


\section{MARKETING}

Lowe's uses a number of marketing channels to reach its customers. National television is used to build brand awareness and managers continue to build relationships and partnerships with networks such as HGTV (Home and Garden Television), BET, and Univision. National radio ads are used to promote major events during the year, especially during key holiday weekends such as the $4^{\text {th }}$ of July. Newspaper and Magazine ads are used to reach customers and remind them of the Everyday Low Price promise and the broad product selection. Direct mail campaigns are used to develop relationships with current and potential customers such as new home buyers. The internet and email are used to share information with customers and subscribers. Customers can participate in an opt-in email program and receive the bi-monthly magazine Lowe's Creative Ideas ${ }^{\circledR}$. Customers can join Lowe's Woodworkers Club, Lowe's Garden Club, and Team Lowe's Racing Fan Club. Gift cards are available as a convenient way for consumers to make purchases. Also business-to-business gift card accounts are available to companies for use as incentives and rewards. Multicultural marketing outlets use print, direct mail, and point of purchase materials to reach out to the growing number of Hispanic and African American customers. Lowe's is a supporter of NASCAR and sponsors Jimmie Johnson, the NASCAR Nextel® Cup Series Champion, and the \#48 car and the $\# 5$ car in the Busch Series, and Lowe's Motor Speedway. In 2006, Lowe's teamed with Adrian Fernandez and Fernandez Racing to field the \#12 car in the Grand American Rolex Sports Car series.

\section{INFORMATION SYSTEMS}

Lowe's managers continuously assess and upgrade information systems to support the company's growth, control costs, and improve decision making. Lowe's has a point-of-sale system, electronic bar code scanning system, a wired and wireless network, and dual UNIX services in each store. Information technology provides managers with real-time perpetual inventory information, support in-store selling functions, provide labor management functions and support administrative functions, and provide customer checkout automated credit card and check approval. The company will open a second data center in 2007 that will allow the company to in-source its disaster recovery capabilities and provide support for future growth.

\section{EMPLOYEES}

Lowe's managers maintain good relationships with the 185,000 employees. Employees receive continuous training to enhance customer skills and product knowledge. Full and part-time employees receive comprehensive benefits along with a $401(\mathrm{k})$ matching and discounted stock purchase program to plan for retirement. The benefits package allows employees to select items to meet individual needs. Options include PPO, HMO, dental plan, flexible spending accounts, vision plan, sick pay, short and long term disability plans, and numerous insurance plans. Part-time employees may participate in the limited benefit health plan, dental plan, short term disability, and term life insurance. Individuals may work in stores, at corporate, in the distribution centers, or as a Lowe's installer.

\section{SOCIAL RESPONSIBILITY ${ }^{26}$}

Lowe's takes its responsibility to be a good corporate neighbor seriously. In FY 2006, Lowe's, its employees, customers, and vendor partners, contributed time and $\$ 15$ million to charitable causes. The following are just a few of the community projects that Lowe's is involved with:

- Habitat for Humanity: Lowe's is a national partner with Habitat for Humanity International and contributed more than $\$ 5$ million in 2006 and employees gave hands-on support at sites across the country. Lowe's is also a national underwriter of Habitat's Women Build program. This program built over 50 homes in 2006.

- $\quad$ American Red Cross: Lowe's partners with the American Red Cross to respond to disasters and distributes the Severe Weather and Natural Disaster Home Readiness Guide free in its stores. Lowe's contributed over $\$ 500,000$ to the American Red Cross in 2006 and has contributed over $\$ 9$ million to recovery programs since 2000 . 
- $\quad$ Home Safety Council: This nonprofit organization was founded by Lowe's in 1993 and provides families with safety information.

- $\quad$ Lowe's Charitable and Education Foundation: During 2006 over $\$ 15$ million in grants was distributed by the Foundation. Projects the Foundation focuses on include community and public school improvement projects, safe and affordable housing, and educational scholarships. The Foundation has partnered with National Geographic Explorer to create an outdoor classroom grant program that provides hands-on natural sciences experiences to children.

- Lowe's Heroes: Lowe's employees volunteer their time and work with local nonprofit organizations in their communities.

- $\quad$ Lowe's Employee Relief Fund: This fund distributes emergency funds to employees who are facing financial hardship due to natural disasters, illness, or house fires. Since 1999 the Fund has helped over 4,000 employees with more than $\$ 5$ million in funds.

- $\quad$ SkillsUSA: In 2007 Lowe's began participating in the SkillsUSA program which is a national student organization that works with businesses and industry to provide relevant job training skills and education on topics such as leadership skills, positive attitude, and pride in workmanship to over 279,000 individuals involved in trade, technical, and skilled service occupations. In 2007, Lowe's will award grants in the amount of $\$ 10,000$ to SkillsUSA chapters for innovative community projects and education program enhancements.

For the $5^{\text {th }}$ consecutive year Lowe's has received the Excellence in Energy Star Outreach Award from the U.S. Environmental Protection Agency in recognition of the company's conservation awareness programs. In 2005, Lowe's installed solar-powered roof top energy generation systems to 3 California stores. Lowe's continues to expand its use of energy efficient technologies that include 'cool roof' technology, high efficiency florescent lighting, air conditioning and heating systems. In 2005, Lowe's recycled 128,000 tons of cardboard, 170,000 tons of pallets and wood waste, and 1,100 tons of shrink wrap. Lowe's continues to expand its eco-friendly product offerings to customers. Michael Chenard, Lowe's director of environmental affairs stated, “As one of the nation's largest green power retail purchases, we are proud to help drive demand toward more responsible energy generation". ${ }^{27}$

Lowe's has a very high standard for wood procurement ${ }^{28}$. The company is committed to: phasing out the purchase of wood products from endangered forests; working with vendors to encourage the maintenance of natural forests; giving preference to the procurement of wood products from independently certified, well-managed forests; working with suppliers to increase the procurement of quality recycled, engineered and alternative products; and to working with customers to increase wood use efficiency. Wood products are sourced by country as follows ${ }^{29}$ :

Country

United States

Canada

Brazil

Germany

Chile
Percent of Overall Volume

60.93
23.93
6.46
2.97
1.26

23.93

1.26

Lowes also offers the following wood alternative products: ChoiceDek engineered components made from reclaimed oak and plastic; recycled rubber mulch that uses old tires; Medium Density Fiberboard, a by-product of manufacturing processes and used in products such as $2 \times 4 \mathrm{~s}$; and plantation grown rubberwood in which older hevea trees are used in making wood products.

Lowe's has a reputation for honesty, social responsibility, and ethical dealings. The company expects each employee to act "1) in accordance with the law, 2) with full consideration of the Company's rights, interests and ethical responsibilities, 3) to protect his own good reputation and also that of the Company, and 4) to scrupulously avoid transactions or situations in which his own interests conflict or could be construed to conflict with those of the Company." ${ }^{30}$ Lowe's Code of Business Conduct and Ethics applies to every employee and director and covers such 
topics as conflicts of interest, confidentiality, fair dealing, protection and use of company assets, compliance with laws and regulations, and reporting of illegal or unethical behavior.

\section{FINANCES}

Although sales fell short of the company's goal, fiscal year ending February 2, 2007, was a strong year for Lowe's Companies. The company reported 8.5 percent net sales growth and 12 percent net earnings growth, but comparable store sales were flat for the year. Although 9 out of 21 regions showed an increase for the year, stores in the Northeast, Florida, and California and other regions were subject to the slowdown in housing that occurred in 2006. Lowe's gained market share in all 20 of its product categories during the year. Only 11 out of the 20 product categories experience an increase in comparable store sales during 2006. Product categories that performed above average in comparable store sales were: rough plumbing, building materials, rough electrical, home environment, paint, fashion plumbing, flooring, nursery, seasonal living, and lawn \& landscape. Outdoor power equipment and lumber product categories experienced the greatest comparable store sales decline. The company imported about $11 \%$ of its products in 2006 compared to $9.5 \%$ in 2005.

Company managers believe there is long term growth and profit potential. The R3 initiative was implemented over the past 2 years and has included numerous supply chain enhancements that will allow the company to operate more efficiently.

During 2007, Lowe's expects to open 150-160 stores. There is a continued commitment to invest in existing stores to keep them up-to-date. The company will spend $\$ 1.3$ billion during 2007 and 2008 to remodel and enhance these stores. During 2006 a new in-home selling model for installation projects like roofing, siding, fencing, and millwork was tested. Initial results were positive and the tests will be expanded in 2007. A new order system to automate the Special Order process was implemented in 2006. Also in 2006 the online kitchen design center was implemented and over 12,000 customers have already used the center to design their new kitchen. Company managers expect a better year in 2007 as the housing slowdown bottoms out and begins to improve and as lumber and plywood prices begin to improve.

The following are 2006 fiscal year end financial reports. ${ }^{31}$

\section{Lowe's Companies, Inc. Consolidated Statements of Earnings}

\begin{tabular}{|c|c|c|c|c|c|c|}
\hline $\begin{array}{l}\text { (In millions, axcapt per share and porountage data) } \\
\text { Fiscal years ended on }\end{array}$ & $\begin{array}{c}\text { February } 2 \text {, } \\
2007\end{array}$ & Sales & $\begin{array}{r}\text { February } 3, \\
2006\end{array}$ & $\begin{array}{r}\% \\
\text { Sales }\end{array}$ & $\begin{array}{r}\text { January } 28, \\
2005\end{array}$ & Sales \\
\hline Net sales (Note 1) & $\$ 46,927$ & $100.00 \%$ & $\$ 43,243$ & $100.00 \%$ & $\$ 36,464$ & $100.00 \%$ \\
\hline Cost of sales (Notes 1 and 15) & 30,729 & 65.48 & 28,453 & 65.80 & 24,224 & 66.44 \\
\hline Grossmargin & 16,198 & 34.52 & 14,790 & 34.20 & 12,240 & 33.56 \\
\hline \multicolumn{7}{|l|}{ Expenses: } \\
\hline Selling, general and administrative (Notes 1,4 and 9) & 9,738 & 20.75 & 9,014 & 20.84 & 7,562 & 20.74 \\
\hline Store opening costs (Note 1) & 146 & 0.31 & 142 & 0.33 & 123 & 0.34 \\
\hline Depreciation (Notes 1 and 3) & 1,162 & 2.48 & 980 & 2.27 & 859 & 2.35 \\
\hline Interest - net (Note 16) & 154 & 0.33 & 158 & 0.37 & 176 & 0.48 \\
\hline Total expenses & 11,200 & 23.87 & 10,294 & 23.81 & 8,720 & 23.91 \\
\hline Pre-tax earnings & 4,998 & 10.65 & 4,496 & 10.39 & 3,520 & 9.65 \\
\hline Income tax provision (Note 11) & 1,893 & 4.03 & 1,731 & 4.00 & 1,353 & 3.71 \\
\hline Net earnings & $\$ 3,105$ & $6.62 \%$ & $\$ 2,765$ & $6.39 \%$ & $\$ 2,167$ & $5.949 \%$ \\
\hline Basic earnings per share (Note 12) & $\$ 2.02$ & & $\$ \quad 1.78$ & & $\$ \quad 1.39$ & \\
\hline Diluted earnings per share (Note 12) & $\$ 1.99$ & & $\$ \quad 1.73$ & & $\$ 1.35$ & \\
\hline Cash dividends per share & $\$ 0.18$ & & $\$ \quad 0.11$ & & $\$ \quad 0.08$ & \\
\hline
\end{tabular}




\section{Lowe's Companies, Inc.}

\section{Consolidated Balance Sheets}

\begin{tabular}{|c|c|c|c|c|}
\hline (In millihns, acept per vilus and percantage datiz) & $\begin{array}{r}\text { Fetruary } 2, \\
2007 \\
\end{array}$ & $\begin{array}{r}x \\
\text { Total }\end{array}$ & $\begin{array}{r}\text { Fetruary 3, } \\
2006 \\
\end{array}$ & $\begin{array}{r}y \\
\text { Total }\end{array}$ \\
\hline \multicolumn{5}{|l|}{ Assets } \\
\hline \multicolumn{5}{|l|}{ Current assets } \\
\hline Cash and cash equivalents (Note 1 ) & $\$ 364$ & 1.396 & $\$ 423$ & $1.7 \%$ \\
\hline Short-term investments (Notes 1 and 2) & 432 & 1.6 & 453 & 18 \\
\hline Me rchandise inventory - net (Note 1) & 7,144 & 25.7 & 6,635 & 270 \\
\hline Deferred income tares - net (Note 11) & 161 & 0.6 & 155 & 0.6 \\
\hline Other curre nt assets & 213 & 0.8 & 122 & 0.5 \\
\hline Total current assets & 8,314 & 30.0 & 7,788 & 31.6 \\
\hline Property, less accumulated depreciation (Notes 3 and 4 ) & 18,971 & 68.3 & 16,354 & $66 A$ \\
\hline Long-term investments (Notes 1 and 2) & 165 & 0.6 & 294 & 1.2 \\
\hline Other assets (Notes 1 and 4 ) & 317 & 1.1 & 203 & 0.8 \\
\hline Total assets & $\$ 27,767$ & $100.0 \%$ & $\$ 24,639$ & $1000 \%$ \\
\hline \multicolumn{5}{|l|}{ Liabilities and shareholder' equity } \\
\hline \multicolumn{5}{|l|}{ Current liabilities: } \\
\hline Short-term borrowings (Note 5) & $\$ 23$ & $0.1 \%$ & - & -96 \\
\hline Current maturities of long-term debt (Note 6) & 88 & 0.3 & 32 & 0.1 \\
\hline Accounts payable & 3,524 & 12.7 & 2,832 & 11.6 \\
\hline Accrued salaries and wages & 372 & 1.3 & 424 & 1.7 \\
\hline Self-insurance liabilities (Note 1) & 650 & 2.4 & 571 & 2.3 \\
\hline Deferred revenue (Note 1) & 731 & 2.6 & 709 & 2.9 \\
\hline Other current liabilities (Notes 1 and 4) & 1,151 & 4.1 & 1,264 & 5.1 \\
\hline Total current liabilities & 6,539 & 23.5 & 5,832 & 23.7 \\
\hline Long-term debt, excluding current maturitiss (Notes 6, 7 and 13) & 4,325 & 15.6 & 3,499 & 14.2 \\
\hline Deferred income tares -net (Note 11) & 735 & 2.7 & 735 & 3.0 \\
\hline Other long-term liabilities (Note 1) & 443 & 1.6 & 277 & 1.1 \\
\hline Total liabilities & 12,042 & 43.4 & 10,343 & 42.0 \\
\hline Commitments and contingencies (Note 14) & & & & \\
\hline Shareholders' equity (Note 8): & & & & \\
\hline Preferred stock $-\$ 5$ por value, none issued & - & - & - & - \\
\hline Common stock $-\$ .50$ par value; & & & & \\
\hline Shares issued and outstanding & & & & \\
\hline February $2,2007 \quad 1,525$ & & & & \\
\hline February 3, $2006 \quad 1,568$ & 762 & 2.7 & 784 & 3.2 \\
\hline Capital in excess of par value & 102 & 0.4 & 1,320 & 5.3 \\
\hline Retained earnings & 14,860 & 53.5 & 12,191 & 49.5 \\
\hline Accumulated other comprehensive income (Note 1) & 1 & - & 1 & - \\
\hline Total shareholders' equity & 15,725 & 56.6 & 14,296 & 58.0 \\
\hline Total liabilities and shareholders' equity & $\$ 27,767$ & $100 . \omega \%$ & $\$ 24,639$ & $1000 \%$ \\
\hline
\end{tabular}




\begin{tabular}{|c|c|c|c|c|c|c|c|c|c|}
\hline Alatoma & 34 & Hawai & 3 & Musuchusetts & 16 & New Hexico & 9 & South Dakota & 3 \\
\hline Alasta & 4 & Idatio & 7 & Michigan & 45 & New York & 43 & Tennssee & 50 \\
\hline Arizona & 23 & Illinois & 34 & Minnesota & 9 & Morth Cardina & 9 & Tewas & 113 \\
\hline Adansas & 19 & Indiana & 41 & Misisippi & 22 & North Dubut & 3 & Utah & 12 \\
\hline Califormia & 83 & Iowa & 10 & Missouri & 34 & ohis & 73 & Virginia & 53 \\
\hline Colorado & 22 & Kansas & 10 & Montan & 5 & ollahom & 26 & Washington & 28 \\
\hline Conneticut & 9 & Kentudy & 36 & Nebrada & 4 & Orgon & 11 & West Virginis & 18 \\
\hline Delaware & 6 & Louisizna & 26 & Nerda & 13 & Penn户̧⿻ & 64 & Wisonsin & 9 \\
\hline Florida & 92 & Maine & 6 & Ner Hampstire & 8 & Rhode Iland & 4 & Wyoming & 1 \\
\hline Georgia & 57 & Maryland & 23 & New Jersy & 34 & Suth Crobin & 40 & Total Shores & 1,35 \\
\hline
\end{tabular}

\section{Lowès Companies, Inc.} Stock Performance (Unaudited)

Quaterly Stock Prike Pange and Cash Dividend Pament

\begin{tabular}{|c|c|c|c|c|c|c|c|c|c|}
\hline & \multicolumn{3}{|c|}{ Fisal 206} & \multicolumn{3}{|c|}{ Fisal 2005} & \multicolumn{3}{|c|}{ Fisol 2004 } \\
\hline & High & Lor & Dividend & High & Lor & Dividend & High & Lor & Dividend \\
\hline lat Quarter & $\$ 4.83$ & $\$ 358$ & $\$ 0000$ & $\$ 2999$ & $\$ 2536$ & $\$ 000$ & $\$ 29.39$ & $\$ 2585$ & $\$ 0015$ \\
\hline 2nd Qunter & 3.85 & 2600 & 0050 & 351 & 2594 & 0000 & 28.6 & 2384 & 0000 \\
\hline ndquarter & 31.5 & 26.15 & 005 & 4.48 & 28.0 & 0030 & 28.8 & 22.95 & 0000 \\
\hline 4th Quarter & $\$ 465$ & $\$ 28.59$ & $\$ 0050$ & $\$ 485$ & $\$ 2983$ & $\$ 0000$ & $\$ 2.27$ & $\$ 27.53$ & $\$ 0000$ \\
\hline
\end{tabular}

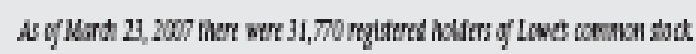




\section{COMPETITORS}

Lowe's major competitors are Home Depot, Menard, and True Value stores.

\section{Home Depot}

Home Depot is the world's largest home improvement chain, the largest retailer in the world, and the second largest retailer in the U.S. The first Home Depot store was opened June 22, 1979, in Atlanta, Georgia, and offered about 25,000 products for sale. Today Home Depot has 2,170 stores in all 50 states, 150 stores in Canada, 61 stores in Mexico, and stores in Puerto Rico and the Virgin Islands. The company entered the Chinese market in 2006 with its acquisition of The Home Way. Between 400 and 500 new stores are planned to open by 2010. The company offers over 40,000 items for sale and the average store size is 105,000 square feet. The company also operates 34 EXPO Design Centers, 11 Home Depot Landscape Supply Stores, and two Home Depot Floor Stores. With 364,000 employees, Home Depot is the world's leading employer of Olympic and Paralympic athletes. ${ }^{32}$ In 2006, the company continued to differentiate itself from its competitors by introducing the most comprehensive lineup of top brand lawn tractors and mowers; launched an expanded outdoor living assortment; launched an exclusive lineup of lithium-ion power tools; and launched the LG® SteamWasher and the Maytag ${ }^{\circledR}$ Epic ${ }^{\mathrm{TM}}$ washer and dryer. The company's three main customer groups are the do-it-yourselfer, the do-it-for-me, and the professional. To enhance its product selection, the company has developed strategic alliances and exclusive relationships with suppliers to market a variety of well-known brand names. Home Depot is growing its service business that includes roofing, flooring, and kitchen fixture installation and is growing its Home Depot Supply business that focuses on professional builders. By 2010 the company expects that $6 \%$ of its revenue will be derived from services and 20\% derived by the Home Depot Supply business. To maintain high quality products, the company sources directly from the manufacturer. To help find new opportunities to include foreign products in its inventory, the company operates four sourcing offices in China -- Shanghai, Shenzhen, Dalian, and Chengdu -- and one office Gurgaon, India. To maintain a cost efficient supply chain, the company operates 18 import distribution centers and 30 lumber distribution centers in the U.S. and Canada. Over 22,000,000 customers visit the Home Depot stores each week.

\section{True Value}

True Value is one of the largest hardware cooperatives in the world. Although owned by entrepreneurs and independently operated, membership in the coop gives store owners a great deal of buying power that allows them to compete effectively with major retailers such as Home Depot and Lowe's. True Value first began in 1947 when John Cotter, a traveling hardware salesman, joined with Ed Lanctot to start a hardware coop. The company grew and by 1989 there were about 7,000 True Value Stores. The company expanded to Canada in 1992 when it acquired Macleod-Stedman. In 1997, Cotter and Company merged with ServiStar Coast to Coast that had 2,800 dealers. In 1999, True Value lost $\$ 131$ million, cut 1,000 jobs and attempted to convert all of its hardware stores chains to the True Value banner (only 1,900 ServiStar stores made the change). Sales continued to decline through 2002 and in January 2003 the company received $\$ 125$ million in financing from W.P. Carey \& Co. To decrease costs the company quit its manufacturing operations in 1995 and sold its oil-based paint manufacturing in 2005 . $^{33}$ Today, True Value Company has about 6,200 stores in 54 countries, 12 regional distribution centers, 3,000 associates and reported over $\$ 2.05$ billion in revenue for $2006 .{ }^{34}$ Comparable company stores sales increased $1.6 \%$ in 2006 and, internationally, the company grew $11.8 \%$.

\section{Menard}

John Menard founded Menard in 1972 and today has 210 stores in Illinois, Indiana, Iowa, Michigan, Minnesota, Nebraska, North and South Dakota, Ohio, and Wisconsin. The company sells home improvement products and is the third-largest home improvement chain in the U.S. In order to remain competitive, Menard began opening larger stores - about 162,000 square feet -- in 2000 when Lowe's began moving in the Chicago market. In 2003, Menard opened a 225,000 square foot store in Indiana and in 2005 opened a 250,000 square foot store in Minnesota. In 2007, the company is building two door manufacturing plants, one in Iowa and one in Ohio. Since 
1995, this privately held company has been plagued by lawsuits filed by customers for false arrest and imprisonment for shoplifting, fines for dumping bags of toxic ash at residential trash pick-up sites rather than at regulated outlets, and owes back taxes and fines because John Menard was paid too high a salary in $1998 .{ }^{35}$ John Menard also owns Team Menard, an Indy car-racing team.

The following provides selected financial and competitive information for top competitors in the home improvement industry. ${ }^{36}$

\begin{tabular}{||c|c|c|c|c|c||}
\hline & Lowe's & Home Depot & Menard* & True Value $^{37}$ & Industry $^{*}$ \\
\hline Annual sales (\$ mil.) & $46,929.0$ & $90,837.0$ & $6,500.0$ & $2,050.0$ & \\
\hline Employees & 210,000 & 364,000 & 35,000 & 2,800 & $11.4 \%$ \\
\hline Gross Profit Margin & $34.5 \%$ & $32.8 \%$ & & $2.3 \%$ & $31.7 \%$ \\
\hline Net Profit Margin & $6.60 \%$ & $6.30 \%$ & & & $2.6 \%$ \\
\hline Return on Equity & $20.7 \%$ & $22.2 \%$ & & & $10.7 \%$ \\
\hline Return on Assets & $11.8 \%$ & $11.9 \%$ & & 1.31 & 1.79 \\
\hline Current Ratio & 1.27 & 1.39 & & & 0.24 \\
\hline Leverage Ratio & 0.16 & 0.22 & & & 0.47 \\
\hline Total Debt/Equity & 0.28 & 0.47 & & & \\
\hline
\end{tabular}

*2005 is most recent information available

\section{LOWE'S COMPANIES INC. TEACHING NOTE}

\section{Overview}

Lowe's Companies is the \#2 firm in the home improvement industry behind The Home Depot. By mid2007, Lowe's operates over 1,385 stores in 49 states and 11 regional distribution centers with plans to enter the Canadian market in 2007 and the Mexican market in 2009. It employs 157,000 full-time and 53,000 part-time people and serves about 13 million customers per week. Fiscal Year End (February 2, 2007) sales were \$46.927 billion and earnings were $\$ 3.105$ billion. Lowe's focuses on the do-it-yourselfer and the do-it-for-me retail customers as well as building professionals. To better service this set of customers, the company offers installation services, provides customers with the opportunity to order unique items not stocked in the store, and provides onestop shopping for commercial customers. Lowe's offers everyday low prices to customers and financing via a proprietary credit card and Lowe's project card. The company is currently pursuing opportunities to better serve the growing Hispanic and African-American customers.

Lowe's carries over 40,000 products in its stores many of which are brand-name merchandise. Products are purchased from 7,000 vendors worldwide. The 11 regional distribution centers ensure that store inventory levels are maintained. Numerous marketing channels are used to reach out to customers. Television is used to build brand awareness, newspapers and magazine ads remind customers of the every day low price promise and product selection, internet and email are used to share information, and direct mail campaigns are used to develop relationships with current and potential customers. Lowe's is highly committed to being a good corporate neighbor by supporting entities such as Habitat for Humanity and the American Red Cross. In addition, the company is conservation-minded and is phasing out wood purchases from endangered forests.

The home improvement industry has experienced about $9 \%$ growth in recent years but it is predicted annual growth will be about $4-5 \%$ in the next 5 years. There are approximately 41,600 stores in the industry. Three types of stores have been identified: hardware stores, home improvement centers, and lumber/building material outlets.

Numerous macroenvironmental changes are affecting the industry: changes in bankruptcy laws and credit criteria, personal income growth, employment growth, demographic trends relating to Generation $\mathrm{X}$ and Generation 
Y home buyers, and changes in technology that affect home products. Internationally, European firms are beginning to expand to markets outside of the EU and the Chinese home ownership market is growing.

The Home Depot, True Value, and Menards are considered direct competitors of Lowe's.

\section{Suggestions For Using The Case}

The case is ideally suited for a Strategic Management course but might also be considered for a Principles of Management course. The industry information provided in the case would allow students to apply industry analysis tools such as identifying industry characteristics, Five Forces competitive analysis, macro-environmental analysis, and key success factors. There is an overview of 3 major competitors so it may be possible to complete a strategic group map analysis. With the company information, a SWOT and financial analysis can be conducted. In addition, the case can provide a basis for discussing a fragmented industry and appropriate competitive strategies. Because Lowe's is the \#2 company in the industry, it would be appropriate to discuss 'follower strategies'.

\section{Teaching Objectives And Suggested Assignment Questions}

Objectives:

- $\quad$ Apply tools to analyze the industry environment

- $\quad$ Apply tools to analyze the internal operations of the company

- Assess the success of the company and how well its operations match the industry environment

Assignment Questions:

- What is the home improvement industry like? What are the characteristics of the industry?

- What macroenvironmental forces are driving changes in the industry?

- What information does a Five Forces competitive analysis of the industry provide?

- What information does a SWOT analysis provide about the condition of Lowe's Companies and its internal operations?

- What is your assessment of Lowe's financial condition?

- What is Lowe's competitive strategy? Is this an appropriate strategy for a follower firm in the home improvement industry? Can Lowe's continue to successfully compete with The Home Depot?

\section{Teaching Outline And Analysis}

\section{What is the home improvement industry like? What are the characteristics of the industry?}

- $\quad$ Market size: The home improvement industry has $\$ 312$ billion in sales in 2006.

- $\quad$ Growth rate: The industry has been growing at a rate of 8 to 9 percent, but future annual growth rate is expected to be 4 to 5 percent. This suggests the industry is moving from a growth stage into a maturing stage.

- $\quad$ Products: hardware, hand and power tools, plumbing/heating products, electrical supplies, paint supplies, home decorating products, and lawn \& garden products. Home improvement centers and lumber/building materials outlets also sell lumber products.

- Rivals: There are over 41,600 stores in the U.S. Twenty-five of the largest companies have $51 \%$ of the market share.

- $\quad$ Market segments: The industry has 3 types of stores. 1) Hardware stores that are smaller in size and serve neighborhoods. Major competitors are True Value, Ace, Do It Best, Trustworth, Sentry, and Pro. 2) Home Improvement Centers are over 100,000 square feet and offer a wide range of products relating to home repair, maintenance, and improvement. Major competitors are Lowe's, Home Depot, and Menard's. 3) Lumber/building material outlets obtain $70-80 \%$ of their sales from lumber building materials. Major 
competitors include 84 Lumber, Lanoga, Stock Building Supply, BMC West, Sutherland Lumber, and Foxworth-Galbraith.

- Scope of Rivalry: Although there are some national chains present in the industry, the geographic area of competition is local.

- Buyers: Two main buyer segments for the industry are retail home-owner customer and professionals. The retail customer falls into two categories of either a do-it-yourselfer or a do-it-for-me. Professionals can include builders, remodelers, and property managers.

2. What macro-environmental forces are driving changes in the industry?

- $\quad$ Economic forces: Changes in bankruptcy laws in the fall of 2005, higher interest rates, and tightening of credit criteria by lending institutions may decrease the number of home buyers. Industry reports indicate that the majority of home improvement spending by individuals occurs within the first six months of home ownership. Personal income is expected to grow 3.4\% in 2006 which has a positive impact on the industry. High employment levels also have a positive impact on the industry. Record levels of home ownership have a positive impact on the industry.

- Demographics trends: Generation Xers are buying homes at younger ages than their parents did. Generation Yers will begin entering the home ownership market in 2007. Continuing high levels of immigration raises the potential of home buyers in the market. Baby boomers are remodeling and buying second homes. Single women are buying homes.

- International/foreign markets: European home improvement companies are beginning to expand outside of the EU. Specifically, Kingfisher (U.K. firm) is expected to expand into the Chinese market. Chinese home ownership laws are changing allowing creating large numbers of potential home buyers. Because flooring, appliances and fixtures are not included in new homes in China, the buyers will need to purchase and install these items.

- Technology: Consumers and home owners are much more energy conscious and are demanding more energy efficient appliances and home products such as windows, insulation, doors, water heaters and furnaces. Technology proficient home buyers/owners request Smart Home Technology be installed in homes. New technology is creating new products for the home. Ovens and refrigerators have smart technology; digital one-touch programming for spa-like baths and steam showers is available; toilets can be heated, self-cleaning, or self-closing; washers and dryers offer features such as a steam cycle and humidity sensors.

3. What information does a Five Forces Competitive analysis of the industry provide?

Using the Five Forces model provides an analysis of the competitive environment of the industry.

- $\quad$ Rivalry among competing sellers: High

Price competition is especially prevalent in the home improvement center segment of the industry and there is a great deal of advertising in this segment. Industry members are continually striving to offer new services (such as installation) and new products to attract customers. Buyer demand is beginning to slow. Buyer switching costs are low.

- $\quad$ Potential Entry of New Competitors: Low to Moderate

Economies of scale are not necessary in this industry, however, power to demand lower prices from product suppliers allows firms to compete on price. There is limited customer loyalty in the industry. Capital requirements to enter the industry are somewhat high, even on a local level - it is necessary to have a building large enough to carry a vast range of products and inventory levels are necessarily high. Capital requirements to enter on a national level and compete with home improvement chains would be quite high. Although profit levels are attractive, industry growth rates are expected to slow. Industry predictions indicate fewer numbers of stores by 2009. Although new entry is possible it is not highly likely. 
- $\quad$ Competitive Pressures from Substitute Products: Moderate-High

Some possible substitutes would include stores outside of the specific home improvement industry that offer the same products would include Wal-Mart, Target, CostCo, wholesalers, brand name stores (such as Maytag appliances, Sherwin Williams paints, etc.), independent stores specializing in one home improvement product (such as nurseries for garden products, home decorating stores, carpet stores for floor products, etc.). Customers could also go to trained professionals such as electricians, plumbers, carpet layers especially for installation services.

Substitute products can be comparably priced and offer similar products. Some substitute products may be able to offer better customer service/expertise. End users have low switching costs.

- $\quad$ Competitive Pressures from Supplier Bargaining power:

For chain stores or stores belonging to a cooperative, supplier bargaining power would be lower. There are many choices or brands of products for companies to carry (note: Lowe's buys from over 7,000 vendors). Company switching costs are low unless the supplier provides private label products. There are few substitutes for hardware products.

For independent hardware stores supplier bargaining power would be higher. These companies do not buy in large quantities, switching costs may be higher, and there are few good substitute products.

- $\quad$ Competitive Pressures from Buyer Bargaining Power:

Professionals: Builders may have higher bargaining power because of potential future purchases or may have large orders, are well-informed, and have low switching costs.

Retail customers: Customers will typically have lower power because purchases are infrequent and in small quantities. However, growth rate (buyer demand) is expected to decline, switching costs are low, and consumers can often choose to delay the purchase of an item.

Overall, even though rivalry is high in this industry, the industry continues to be attractive. Chain companies, such as Lowe's, and cooperatives have power over suppliers; substitutes are a moderate threat, but it is apparent that home improvement/hardware stores can successfully compete with substitutes; there is a limited threat of new entrants into the industry; and there are many market and customer segments to be served by firms in this industry.

\section{What information does a SWOT analysis provide about the operations at Lowe's Companies?}

Lowe's appears to be a very well run company that has many strengths, but few weaknesses.

Strengths:

- Joint ventures and partnerships with firms such as Snap-on tools

- $\quad$ Located in 49 states

- 11 regional distribution centers to serve stores

- $\quad \$ 46.927$ Billion in sales for FYE 2006

- $\quad \$ 3.105$ billion in earnings for FYE 2006

- $\quad$ Ranked \#45 on the 2007 Fortune 500 list

- $\quad$ Named one of Forbe's best managed companies in America

- $\quad$ Rated one of the top 10 companies offering opportunities to Hispanics by Hispanic Magazine

- $\quad$ Serves over 13 million customers each week

- $\quad$ Guarantees everyday low prices

- $\quad$ Good vision statement

- $\quad$ Appropriate growth plans for the future (the market will bear the new stores, the company can finance them)

- $\quad$ Two types of stores for two different markets: 116,000 square foot stores for large markets and 94,000 square foot stores for smaller markets 
- $\quad$ Aware of shifts in the market - for example Lowe's offers installation services in over 40 categories for the fairly new market segment the do-it-for-me customer

- $\quad$ Offers a Special Order Sales program

- Works closely with professional to provide one-stop shopping needs - contractor packs, job-site delivery, special web site, fax or phone orders for same day pickup.

- $\quad$ Financing for customers through proprietary credit card, project card

- $\quad$ Services and information for Hispanic and African-American customer

- $\quad$ Sells over 40,000 products

- $\quad$ Offers many name brand products

- $\quad$ Shares order information electronically with suppliers

- $\quad$ Buys direct from manufacturer when possible

- $\quad$ Implemented the Rapid Response Replenishment (R3) initiative

- Uses numerous marketing channels to reach customers - television, newspapers, magazines, direct mail, internet, \& email.

- $\quad$ Continuously upgrades information systems

- $\quad$ Numerous benefits for both full time and part time employees

- $\quad$ Training of employees so they have good product knowledge and can better help customers

- $\quad$ Code of Ethics

- $\quad$ Social Responsibility - supports Habitat for Humanity and the American Red Cross. The company also has a Home Safety Council, Charitable and Education Foundation, and Employee Relief Fund.

- $\quad$ The company saves energy whenever possible

- Recycles

- $\quad$ Offers eco-friendly products

- $\quad$ High standard for wood procurement - decreasing purchases from endangered forests

- $\quad$ Financially strong: $8.5 \%$ sales growth, $12 \%$ net earning growth

Weaknesses:

- $\quad$ \# 2 firm in the industry

- $\quad$ Limited information about how technology is used at distribution centers - may be possibilities for bar codes, automatic order filling capabilities, etc.

- $\quad$ Flat comparable store sales

Opportunities:

- $\quad$ Untapped markets such as rural areas, bedroom communities, urban areas

- $\quad$ Personal income is expected to grow

- $\quad$ Employment growth

- $\quad$ High levels of home ownership

- Generation X home buyers

- $\quad$ Generation Y individuals may begin buying homes by 2007

- $\quad$ Single women purchasing homes

- $\quad$ Growing number of Hispanics and African Americans becoming home buyers

- Home ownership in China is now allowed

- Developing countries that have a growing middle class or increased affluence

- New technology used in home products and appliances

- $\quad$ New kinds of building materials

- $\quad$ Trend among home buyers to have more personal home designs

- $\quad$ Trend among home buyers to request smart home technology, home offices, outdoor living spaces, finished basements, home theaters

- $\quad$ More customers using the internet to shop and obtain information 
Threats:

- $\quad$ 41,600 competitors - Independent stores that offer customer service; other chain stores

- $\quad$ Predicted future growth of only 4-5\% annually

- $\quad$ Predicted fewer number of stores by 2009

- $\quad$ High interest rates

- $\quad$ Bankruptcy laws

- $\quad$ Tightening of credit criteria by lenders

- $\quad$ Substitute products

5. What is your assessment of Lowe's financial condition?

- Lowe's appears to be in solid financial condition

- Lowe's has beaten the industry average for many profitability ratios.

- $\quad$ Other ratios indicate the company fairs well when compared to industry averages.

- $\quad 2006$ FYE sales $\quad \$ 43,243.0$ million

- 1 year sales growth: $\quad 8,5 \% \quad$ Industry: $8.5 \%$

- 1 year net income growth: $\quad 12.3 \% \quad$ Industry: $6.2 \%$

- 36 month revenue growth: $\quad 52.2 \% \quad$ Industry: $52.2 \%$

- 36 month net income growth: $\quad 65.4 \% \quad$ Industry: $65.4 \%$

Key financial statistics for FYE 2006 (dated February 2, 2007) include:

$\begin{array}{lllll}\text { - } & \text { Gross Profit Margin: } & 34.50 & \text { Industry: } & 31.70 \% \\ \text { - } & \text { Net Profit margin: } & 6.60 \% & \text { Industry: } & 3.60 \% \\ \text { - } & \text { Return on Assets: } & 11.8 \% & \text { Industry: } & 10.0 \% \\ \text { - } & \text { Return on Equity: } & 20.7 \% & \text { Industry: } & 20.7 \% \\ \text { - } & \text { Current Ratio: } & 4.5 & \text { Industry: } & 4.9 \\ \text { - } & \text { Quick Ratio: } & 1.27 & \text { Industry: } & 1.79 \\ \text { - } & \text { Total Debt/Equity } & .28 & \text { Industry: } & 1.1 \\ & & & \text { Industry: } & 0.47\end{array}$

Stock price (June 2006 to June 2007):

- $\quad 52$ week high $\quad \$ 35.74$

- $\quad 52$ week low $\quad \$ 26.15$

- $\quad$ P/E ratio 16.55

6. What is Lowe's competitive strategy? Is this an appropriate strategy for a follower firm in the home improvement industry? Can Lowe's continue to successfully compete with The Home Depot?

Lowe's competitive business level strategy is a low cost provider. Lowe's is able to keep costs low through by purchasing in large quantities from suppliers, buying directly from manufacturers, using technology to control costs, and setting up distribution centers to service area stores.

As a follower (\#2 in the industry), a firm should not be implementing the same strategy as the market leader. In this case The Home Depot is implementing a low cost provider strategy but focuses on serving the do-ityourself consumer buyer. Home Depot is also developing more in the international markets. Lowe's customer focus is on the professional, the do-it-yourself consumer, and the do-it-for-me consumer. Lowe's expansion plans are for domestic expansion with a small movement into the Canadian market in 2007 and the Mexican market in 2009. In some cases, Lowe's is on the cutting edge of market trends with Home Depot employing a follower 
strategy. This has happened in the installation services area. Menard's, as \#3 in the market, is implementing a focused low cost strategy by maintaining its presence in the mid-west region.

To date, it appears that Lowe's is successfully competing with Home Depot in the home improvement market. Financial results (comparing ratios) are similar. Neither firm is reporting any problems such as sales declines, legal issues, customer declines, etc.

${ }^{1}$ Do-It Yourself Retailing, Annual Report, December 2005

${ }^{2}$ National Retail Hardware Association/Home Center Institute Report

${ }^{3}$ Financial Times UK, Companies the Americas: Door closes on boom times for DIY stores, May 22, 2006

${ }^{4}$ Waters, Jennifer, Marketwatch, Lowe's sees trend of housing normalization, May 22, 2006.

${ }^{5}$ Biesada, Alex, Hoovers On-line, Home improvement \& Hardware Retail, 2006

${ }^{6}$ Building online (July 28, 2006). HIRI says home improvement industry thriving despite housing slowdown. Online at www.buildingonline.com/news

${ }^{7}$ National Retail Hardware Association/Home Center Institute Report

${ }^{8}$ Do-It Yourself Retailing, Annual Report, December 2005

${ }^{9}$ Lowe's Companies Inc. 2006 Annual Report.

${ }^{10}$ Yahoo Finance (May 9, 2007). Retail, Home Improvement. Online at: http://biz.yahoo.com

${ }^{11}$ Nelson, T. (February 5, 2006). Retail Home Improvement, Henry Fund Research.

${ }^{12}$ Ibid

${ }^{13}$ Nelson, T. (February 5, 2006). Retail Home Improvement, Henry Fund Research

${ }^{14}$ Ibid.

${ }^{15}$ Biesada, Alex, Hoovers On-line, Home improvement \& Hardware Retail, 2006

${ }^{16}$ YaHoo Finance (May 2007), Home Improvement \& Hardware Retail Industry Profile, online at http://biz.yahoo.com

${ }^{17}$ Ibid

${ }^{18}$ Review: HK Lighting Fair, HK Int'l Hardware \& Home Improvement Fair, October 2005, online at http://tradeshow.globalsources.com

${ }^{19}$ Lowe's Website, News Release, Jan 12, 2006, on-line at http://lowes.mediaroom.com

${ }^{20}$ Lowe's Website, News Release, April 24, 2006, on-line at http://lowes.mediaroom.com

${ }^{21}$ Ibid

${ }^{22}$ Lowe's 2006 Annual Report and SEC Form 10-K for period ending 2/2/2007.

${ }^{23}$ Hoover's on-line, 2006, Lowe's Companies Inc., profile at http://0-premium.hoovers.com

${ }^{24}$ Lowe's Companies website, 2007, online at http://www.lowes.com

${ }^{25}$ Nelson, T. (February 5, 2006). Retail Home Improvement, Henry Fund Research.

${ }^{26}$ Lowe's 2006 Social Responsibility Report and 2006 Annual Report

${ }^{27}$ PRNewswire, March 10, 2006, 'EPA Recognizes Lowe's as One of Top Green Power Purchasers'. On-line at http://lowes.mediaroom.com

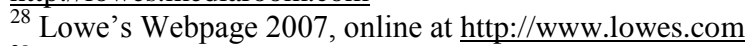

${ }^{29}$ Lowe's Webpage, 2006, on-line at http://www.lowes.com

${ }^{30}$ Lowe's Companies Code of Ethics, online at http://www.shareholder.com/lowes

${ }^{31}$ Lowe's Companies, 2007 fiscal year end annual report, on line at www.shareholder.com/lowes

${ }^{32}$ Home Depot Webpage, 2007, on line at http://corporate.homedepot.com

${ }^{33}$ Hoovers On line, 2007, True Value profile at http://0-premium.hoovers.com

${ }^{34}$ True Value Webpage, 2007, at www.truevaluecompany.com

${ }^{35}$ Hoovers on line, 2006, Menard company profile, at http://0-premium.hoovers.com

${ }^{36}$ Hoovers on line, 2007, competitive landscape information, at http://0-premium.hoovers.com

${ }^{37}$ True Value Annual Report for 2006, available online at http://www.truevaluecompany.com 
NOTES 